\title{
Genevieve Walton and Library Instruction at the Michigan State Normal College
}

\section{Clare Beck}

From 1892 to 1932, the library of the Michigan State Normal College was directed by Genevieve Walton, who developed a one-room, one-person operation into a full-fledged academic library. The focus of this paper is on Walton's development of a course in library instruction for students at the college. Using archival records, the paper describes her course in library use, her active involvement in the educational process, and her determination that librarians function as college faculty. Walton's work is related to historical patterns of bibliographic instruction, particularly as it developed in normal colleges, and to published assertions about the history of bibliographic instruction. Directions for further research are suggested.

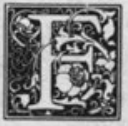

or forty years, from 1892 to 1932, the library of the Michigan State Normal College (now Eastern Michigan University) was directed by Genevieve Walton, who developed what had been a one-person, one-room establishment into a library more appropriate to an institution of higher education. Walton guided the growth of the collection to 70,000 volumes, consistently one of the ten largest collections among teachers colleges and evaluated by Edmon Low as superior in quality to most of them. She developed a full-time staff of eleven and a separate library building which, at its opening in 1930, was considered "sumptuous" in its capacity for 150,000 volumes and 400 students. ${ }^{1}$ Walton also was a leader of the library profession, actively participating in the American Library Association and the Michigan Library Association of which she was a co-founder and first woman president. Many testimonials by her contemporaries praised her intelligence, professionalism, and personal qualities. In recent years,
Laurel Grotzinger has called attention to her career, using the title of one of Walton's own speeches, "The Lost Librarian," to describe her current obscurity as an example of "how little the library profession knows and values its heritage." "2

An aspect of Walton's career that has not been discussed is her work in instructing students in library use and relating such bibliographic instruction to the overall educational mission of the college and the status of librarians. Exploration of this early effort in bibliographic instruction is more than an historical curiosity, for it casts light on several recent publications in library history that are related to how the profession perceives itself. One of these, Peter Hernon's "Instruction in the Use of Academic Libraries: A Preliminary Study of the Early Years as Based on Selective Extant Materials," found that the records of pre-1914 bibliographic instruction are practically nonexistent at the institutions he visited. ${ }^{3}$ Hernon urges more research into the history of library instruction,

Clare Beck is Government Documents Librarian at the University Library, Eastern Michigan University, Ypsilanti, Michigan 48197. This paper was presented in a slightly different form to the Library and Information Science Section of the Michigan Academy of Science, Arts, and Letters. 
including efforts to ascertain whether "the existence of certain types of archival records might provide a more complete picture of institutional programs.",4 Because the archives of Eastern Michigan University include Walton's course notes and outlines from 1900 to 1928 , as well as recollections of librarians who knew her as students, such a picture of her approach to library instruction is available.

Another relevant article, Frances Hopkins' "'A Century of Bibliographic Instruction: The Historical Claim to Professional and Academic Legitimacy," denigrates both women librarians and normal college librarians by asserting that Melvil Dewey's practical training and encouragement of women librarians "depressed the profession" because "most of the new library school graduates were neither the intellectual nor social equals of academic faculty." ${ }^{5}$ The semiclerical nature of their work, she argues, led to the "decline from instruction in use of library materials for research to instruction in access procedures" and a shift in emphasis from the scholarly approach of Justin Winsor at Harvard to "teaching basic access skills to freshmen in normal schools and agricultural colleges. ${ }^{\prime 6}$

Anita Schiller and others have pointed out how simplistic it is to argue that women depressed the library profession,? and the fallacy of generalizing about American higher education from the example of Harvard should be obvious. Even though Hopkins' assertions are questionable at face value, it may be useful to consider them also in relation to what Walton actually did in a normal college in the early years of the century. Such examination will show that she had a number of aims that amounted to considerably more than what Hopkins describes.

\section{COURSES IN LIBRARY USE}

Walton initiated courses of lectures on library use soon after she arrived at the college in 1892. Of her initial efforts, we have only the description in the 1894-95 college catalog:

As heretofore the Librarian has given two courses of lectures, one each semester, upon the nature, handling and uses of a library, and its collection, with especial reference to the Normal School Library. The subjects of the several lectures were:

1. Ancient Writing Material and Manuscripts

2. Printing and the Printing Press

3. Libraries

4. Catalogues and Classification

5. Reference Books and How to Use Them

6. Selection and Buying of Books for Private and Small School Libraries. ${ }^{8}$

The catalog also explains, in words presumably written by Walton, the rationale for the lecture series:

Every means is employed to make the library a working instrument for the school as a whole. ... There are also certain laboratory functions of a library which readily respond to every grade of earnest, investigative, out reaching instruction. It affords to such students as have mastered the handling of books, an open field for exploration and comparative studies. ...?

The lecture series soon evolved into a course that met, usually on Saturdays, for eight two-hour sessions that were attended by ten to fifty students. Credit was not granted for the course, but Walton offered some strong incentives for students to give up their Saturday mornings: only those who had taken the course were granted access to the library's closed stacks and were eligible for employment in the library. Thus her classes were likely to consist of the more serious, bookish students who were motivated to learn about the library and gain access to the stacks. Some may also have had a pecuniary interest in a job in the library; though wages were modest, students at Michigan State Normal College often were dependent on part-time jobs to work their way through school. Walton emphasized the former motivation, telling her students that "instruction, and the privilege of more generous use of the stacks and the books [was] a good equivalent" for the credits they did not receive. ${ }^{10}$ Indeed, she seems to have used the absence of credits to encourage esprit de corps (one of her favorite terms), assuring her students that they were an elite group of the highest academic standing who had elected to take a noncredit course.

Then, as now, the desirability of credit for library instruction was recognized. By 
not providing credit or connection with an existing credit course, Walton probably lost opportunities to reach some students. There were advantages, however, that reflect Walton's well-known ability to get things done. ${ }^{11}$ Given that she had other incentives to draw students, the absence of credit enabled her to avoid the always delicate process of obtaining approval from faculty and administration for any addition to the curriculum. And by connecting the course with the selection and preparation of library assistants, Walton justified keeping such instruction under her control.

Walton always emphasized that the work experience of student assistants was an important part of their education. They were not just cheap labor to be trained in simple routines. She sometimes carried this attitude to extremes, as in her resistance to Cutter numbers on the grounds that she wanted student shelvers to be force to examine each book's author and title, not just shelve automatically by numbers. ${ }^{12}$ Requiring potential employees to take her course was a logical reflection of Walton's pedagogical approach and high expectations of student assistants.

\section{"Walton was in the mainstream of the late-nineteenth-century move- ment to develop libraries as laborato- ries for independent reading, offer- ing an alternative to textbooks."}

Walton did not describe the course as a training program for the clerical routines of student assistants nor as an introduction to librarianship. Instead, she consistently stated, "This course is not to train librarians, but to train teachers to use books, and to help others to use them. ${ }^{\prime 13}$ Thus, Walton was in the mainstream of the late-nineteenth-century movement to develop libraries as laboratories for independent reading, offering an alternative to textbooks. She was not just encouraging this among college students but was trying to train teachers who would make library use a part of the education of schoolchildren. According to Frederick
Cleveringa, many students "became interested in books through Miss Walton, and if they weren't interested in books from the librarian's point of view, at least they were better teachers, especially of English, than they were before they took the library courses." 14

The class assignments and discussions were closely related to Walton's own deep interests in art and literature. Walton aimed to relate library access to the wider world of culture that books and libraries represented to her and many librarians of her generation. Certainly she had to teach basic methods of access to students with limited library experience, for as she pointed out, "a large percentage of these students have always come from the country, or from small towns with no libraries." ${ }^{15}$ Her emphasis, however, was always on the broader concept, "to accustom a large body of students to depend upon the intelligent use of books in teaching. ${ }^{16}$ While practical training of student assistants was one of Walton's aims, her primary efforts were to relate library instruction to the college's vocational objective, the preparation of teachers, and its wider academic goals of developing students' cultural awareness.

A more specific look at the content of Walton's course as revealed by her 1900-28 notes and outlines indicates the course covered the standard categories of library use: the card catalog, classification system, major reference books, and periodicals and their indexes. The material on the history of books and libraries that was part of her early lecture series seems not to have been included. Much of the course, such as her assignments to review such reference books as the World Almanac and the Statesman's Yearbook, could be used unchanged today. Walton's teaching covered considerably more, however, and two aspects seem to have been at least as important as the practical methods of library organization and use.

\section{BROAD EDUCATIONAL ROLE}

General cultural awareness and encouragement of serious reading were integral to the course. The roll call that began each class meeting would include responses to assignments such as a report on a book 
each student would like for Christmas or a report on a novel assigned the previous week. A lecture might begin with Walton's account of a visit to the Freer Collection of Art (then located in Detroit), including Whistler's famous Peacock Room; the students were then assigned to prepare bibliographies on Whistler and the Freer Collection. Students did not examine only reference books; they were assigned to read and discuss the works of great poets and novelists. Periodicals were not considered only in terms of the mechanics of using indexes; attention was given equally to the intellectual character of the leading periodicals and their editors. In that era, when noted editors were closely identified with their publications, Walton expected her students to be aware of, for example, Ellery Sedgewick's connection with the Atlantic. In addition to assignments to look up subjects in the Readers' Guide, students were expected to report on such topics as "What magazines do you read for just pure pleasure, and what articles do you read for personal advancement?".

"In the early part of the century,
guidance in manners and morals was
an accepted role of the college fac-
ulty, and Walton apparently had no
doubt of the appropriateness of in-
cluding it in her library instruction."

The emphasis on reading was characteristic of Walton, who often was praised for her ability to "discuss books so that you can hardly wait to read the ones she talks about." ${ }^{17}$ From all accounts, she was a librarian who did not particularly distinguish between the love of reading and the work of organizing and processing library books. Thus, it was natural for her to integrate the teaching of library access with her own reverence for literature and her basic faith in "the joys and lasting satisfaction that come from being fond of books." 18

Another aspect of the course that dem- onstrated how broadly Walton saw her educational role was the emphasis on what she called "social ethics," which seems to have been an amalgam of advice on genteel behavior (don't use toothpicks in public), courtesy (don't look through other people's desks), psychology (a discussion of personality types), and invocation of high ideals (as in her final instruction to her students: "Be true. Be loyal. Be courteous. Hold high the honor of your college."'). Much of this seems quaintly dated, but, in the context of the times, it was the equivalent of the pop psychology and how-to advice that bombards us today. As Walton urged her students in 1910 to cultivate a "neat and fresh appearance," so today leading graduate schools of business and best-selling writers teach how to "dress for success"; ; both seem examples of our American fascination with the possibilities of self-improvement. Since the social ethics discussion seems to have been scheduled for the middle of each class session, Walton may have used it to revive interest at a point when students attention might tend to wander from classification or catalog entries. Certainly it shows her confidence in herself as an educator who could guide the development of students' values and personal behavior as much as she explained the techniques of using the library. In the early part of the century, guidance in manners and morals was an accepted role of the college faculty, and Walton apparently had no doubt of the appropriateness of including it in her library instruction.

The breadth of Walton's educational effort is best summed up by one of her students, Wanda Bates:

She impressed her library students with the importance of integrity, a desire to know more about literature, a sense of a job well done and the importance of high and definite goals in life. She was a perfectionist and would not accept slovenly work. . . . She often presented an excerpt from a book or article and urged every student to read some of the best in literature.... . Perhaps most remembered was her ability to draw students out as to their desires and ambitions. She could give a student in whom she was interested a sense of personal worth that would hold his admiration for her. She helped many students with counsel, funds, and social 
recognition. She often invited a student or two, along with a few adults, to her house for lunch ... [where she] talked of books, authors, world events. ${ }^{19}$

This is the description of a dedicated and effective teacher who, in the context of her time and institution, cannot be considered inferior to Justin Winsor or other prominent librarians of that era. In some cases, the bibliographic instruction of others may have been more scholarly in its orientation than Walton's, but scholarship at that time was not as specialized and technical as it is today, and all academic librarians were dealing with students who did not have much experience in using libraries. To a great extent, Walton and Winsor and all of the pioneers of library instruction were following Emerson's call for a "professor of books, ${ }^{\prime 20}$ and the similarities of their efforts seem greater than the differences.

\section{LIBRARIANS AS COLLEGE FACULTY}

Not surprisingly for one so certain of the educational role of the librarian, Walton considered librarians full members of the college faculty. In the words of her colleague Wanda Bates:

She did all college librarians a service by establishing her staff as members of the college faculty with all rights and privileges. This position was assailed at various times ... . but she steadfastly maintained that the staff were teachers and that to us the student was the important part of the college. She never allowed us to forget that we were expected to participate in college activities so that we could merit this standing. ${ }^{21}$

Indeed, the library's Staff Manual specified that librarians were expected to attend meetings of the college faculty. ${ }^{22}$

Attendance at professional and educational meetings also was strongly encouraged. The 1912 Staff Manual even specified that two workdays were to be devoted to visiting other libraries, in keeping with Walton's belief that professionalism involved acquaintance with libraries and librarians outside the immediate workplace. ${ }^{23}$ Francis Goodrich recalled, "She was always an office holder of some sort and encouraged her assistants to go and take part" in professional organizations. ${ }^{24}$ Besides holding office in the Michigan Library Association, Walton was a leader in the round table movement, traveling the state to bring together small town librarians to share information and raise standards.

Long before graduate degrees were standard for academic librarians, Walton encouraged her staff to pursue graduate study at the nearby University of Michigan. Frederick Cleveringa explained:

After we had our bachelors degree ... we all took part time over to the university, pegging along on our degrees over there, and Miss Walton was quite insistent upon that. She said 'I don't want you to stagnate, I want you to keep on going.' So our schedule was arranged so that we could take a two or three hour subject over there every semester, and she was quite generous in that way. ${ }^{25}$

Besides the intellectual stimulation, graduate degrees were important to the librarians' faculty status, since the Michigan State Normal College faculty had the highest proportion of graduate degrees of comparable schools and President McKenney was a nationally prominent advocate of graduate training for normal college teachers.

"'She encouraged us to read-and in fact we had to read. She would inquire what we were reading and she wanted her staff members to be up to date. ... That was quite insisted upon.'

Walton's determination that her staff not stagnate was not limited to the quantifiable credentials of courses taken and meetings attended. Perhaps her greatest concern was that her staff keep up their reading as avidly as she did. The staff manuals stated firmly that "a librarian must be constant in reading, both general and professional, to worthily fulfil his work." ${ }^{26}$ The enforcement of this provision was described by Francis Goodrich: "She encouraged us to read-and in fact 
we had to read. She would inquire what we were reading and she wanted her staff members to be up to date. ... That was quite insisted upon. ${ }^{\prime 27}$

Walton also placed great faith in the educational value of travel, particularly to Europe, where she had studied art as a young woman and visited on at least three later occasions. Since the college's librarians had long summer vacations, European travel was another of the things that Walton expected. She took her assistant, Elsie Andrews, along on several of her own trips; and in at least one instance, Walton loaned her own money to pay for a staff member's summer in Europe, on the generous terms that "you can pay that back whenever you can, I don't care when." 28

Clearly, Walton put considerable effort into developing a staff that was not likely to settle into clerical routines or be perceived as inferior to the faculty. While setting high standards, she gave both practical support and the example of her own dedication as "one who inspired those under her by her own untiring devotion. ${ }^{\prime 29}$

\section{WALTON'S WORK AS PART OF LIBRARIANSHIP HISTORY}

In relation to the history of librarianship, the question is how typical were Genevieve Walton's efforts and achievements? Where does she fit in the patterns of development of bibliographic instruction, women librarians, and academic librarianship?

Certainly Walton's contemporaries considered her praiseworthy, even exceptional. But as Grotzinger, Hernon, and Mary Niles Maack have pointed out, we don't really know all that much about either the first generation of women librarians or the early programs of library instruction. ${ }^{30}$ John Tucker's bibliography on pre-1933 library instruction and the U.S. Commissioner of Education's 1914 study of library instruction show that Walton's efforts were not unique, that in fact many colleges had comparable or more extensive programs of bibliographic instruction. ${ }^{31}$ Much of that instruction was being conducted by women librarians in normal colleges. This brings us back to Hopkins' assertion that there was a decline from the higher sort of instruction at prestigious schools to the mere access training in normal colleges. ${ }^{32}$ We have seen that Walton's efforts at Michigan State Normal College amounted to more than that, and we need to look more closely at the work of librarians in normal colleges as an aspect of library history that has not received attention.

In 1910 , there were 264 normal colleges educating more than 88,000 students. $^{33}$ Beyond the numbers, it is difficult to generalize, because these schools varied from small county-run establishments to leading institutions with full academic programs and facilities comparable to other colleges. Though their name and function caused them to be categorized as a separate group, they were not necessarily inferior to or even significantly different from other schools. At least one aspect of their history is particularly relevant to the history of American librarianship. As Egbert Isbell points out in his history of Eastern Michigan University, a "noteworthy aspect of the Normal faculty was the role played by women. Free from the longstanding prejudice in major institutions of learning against women on the faculty, the Normal from the first benefitted by this. ${ }^{\prime 34} \mathrm{He}$ goes on to name some of the notable women faculty, including Genevieve Walton. Thus, we have Isbell's picture of able women achieving in an atmosphere relatively free of prejudice versus Hopkins' view of inadequately educated women librarians providing second-rate instruction.

As Hernon suggests, researchers in library history need to delve into the archives of the normal colleges, most of them now state colleges and universities, in search of the records of Walton's contemporaries. Perhaps we ultimately will conclude that library instruction changed more in location than quality in the first third of the twentieth century, and, as collection growth required more attention in large university libraries, much of the leadership in library instruction shifted to normal colleges, where women librarians were able to make full use of their abilities. 


\section{REFERENCES AND NOTES}

1. Egbert Isbell, History of Eastern Michigan University, 1849-1965(Ypsilanti, Mich.: Eastern Michigan Univ. Pr., 1971), p.296, 300.

2. Laurel Grotzinger, "Women Who Spoke for Themselves," College \& Research Libraries 39:188 (May 1978).

3. Peter Hernon, "Instruction in the Use of Academic Libraries: A Preliminary Study of the Early Years as Based on Selective Extant Materials," Journal of Library History 17:16-38 (Winter 1982).

4. Ibid., p.33.

5. Frances L. Hopkins, "A Century of Bibliographic Instruction: The Historical Claim to Professional and Academic Legitimacy," College \& Research Libraries 43:194 (May 1982).

6. Ibid., p.194.

7. Anita Schiller, "Women in Librarianship," in The Role of Women in Librarianship, 1876-1976; The Entry, Advancement, and Struggle for Equalization in One Profession, ed. Kathleen Weibel and Kathleen M. Heim (Phoenix, Ariz.: Oryx Pr., 1979).

8. Yearbook of the Michigan State Normal School 41:40 (1894-95).

9. Ibid., p.37-38.

10. Genevieve Walton. Class notes and outlines, G. Walton file box, Eastern Michigan University Archives. All references to Walton's classes are from this assortment of handwritten and typed notes from various years in the period 1900 to 1928 .

11. "Miss Walton," Normal College News May 5, 1932, p.1.

12. Egbert Isbell interview with Frederick Cleveringa, Sept. 19, 1960. Transcript in F. Cleveringa biographical file, Eastern Michigan University Archives.

13. Walton class notes.

14. Isbell interview with Cleveringa, p.4.

15. Isbell, History, p.299.

16. Ibid.

17. Elisabeth Knapp, "From Miss Knapp," Michigan Library Bulletin 21:75 (Mar. 1930). This special issue dedicated to Walton contains many tributes to her.

18. "Miss Walton," Normal College News, May 5, 1932.

19. Wanda Bates, "Reminiscences," p.9-10. Undated typescript in Eastern Michigan University Archives.

20. John Mark Tucker, "The Origins of Bibliographic Instruction in Academic Libraries, 1876-1914," in New Horizons for Academic Librarians, ed. Robert D. Stewart and Richard D. Johnson (New York, Saur, 1979).

21. Bates, "Reminiscences," p.10-11.

22. Staff Manual, 1930. Library documents box, Library Staff Manuals folder, Eastern Michigan University Archives.

23. Staff Manual, 1912. Library documents box, Library Staff Manuals folder, Eastern Michigan University Archives.

24. Egbert Isbell interview with Francis Goodrich, Nov. 8, 1956, p.5. Transcript in Eastern Michigan University Archives.

25. Isbell interview with Cleveringa, p.7.

26. Staff Manual, 1930, p.3.

27. Isbell interview with Goodrich, p.5.

28. Isbell interview with Cleveringa, p.3.

29. "Miss Walton," Normal College News, p.1.

30. Mary Niles Maack, "Toward a History of Women in Librarianship: A Critical Analysis with Suggestions for Further Research," Journal of Library History 17:164-85 (Spring 1982).

31. John Mark Tucker, Articles on Library Instruction in Colleges and Universities, 1876-1932, University of Illinois Graduate School of Library Science Occasional Papers, no.143 (Feb. 1890), ED 187 330; and Henry R. Evans, "Library Instruction in Universities, Colleges, and Normal Schools," U.S. Bureau of Education Bulletin, no.34 (Washington, D.C.: Govt. Print. Off., 1914).

32. Hopkins, "A Century of Bibliographic Instruction," p.194.

33. U.S. Commissioner of Education, "Report . . . for the Year Ended June 30, 1910"'(Washington, D.C.: Govt. Print. Off., 1911), p.1075.

34. Isbell, History, p.xiv. 